\title{
As bandas de música populares en Galicia
}

DOI: 10.17075/bmpg.2021

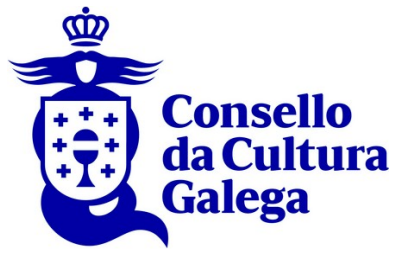

Pazo de Raxoi, $2^{\mathbf{0}}$ andar

Praza do Obradoiro, s/n

15705 Santiago de Compostela

+34981957202

consellodacultura.gal 


\section{Índice}

\section{Presentación}

1. Introdución

2. Metodoloxía

2.1. Obxectivos

2.2. Cuestionario e mostra

2.3. Contidos do informe

3. A dimensión social das bandas de música populares en Galicia

3.1. Datos xerais das entidades

3.2. Características dos intérpretes

3.3. A dirección

3.4. As escolas de música das bandas

3.5. Xestión e infraestruturas

3.6. Actividade

3.7. Financiamento

3.8. Público

3.9. Difusión e imaxe

3.10. A incidencia da COVID-19

3.11. Desafíos e demandas

4. Conclusións 


\section{Presentación}

Galicia é un país cunha ampla cultura musical de seu, que temos que coidar e poñer en valor constantemente, como peza identificadora da nosa realidade e como parte do noso patrimonio.

No transcorrer do tempo a música e as formas de expresión evolucionaron, dende os cantares dos trobadores ata as múltiples formas e agrupacións que coñecemos hoxe en día. Entre eses distintos xeitos de expresión musical que se foron incorporando á nosa cultura están as bandas de música populares, que viven na actualidade un momento de auxe enorme en toda Galicia.

As bandas civís fan a súa aparición a comezos do ano 1800. É evidente que nacen a imitación das militares, posto que a disposición instrumental é a mesma e os músicos gardan uniformidade no desfile e na vestimenta, pero tamén teñen as súas diferenzas, posto que a súa función non ten nada que ver coa guerra. Por outra parte, cómpre salientar que xorden dos movementos asociacionistas que traen os novos pensamentos liberais daquel entón e deixan dende ese momento de pertencer exclusivamente a certos estamentos como poden ser a alta burguesía, a nobreza, os mandos militares ou o clero. Eran as bandas de música populares.

É así como a música culta se estende e chega ata o pobo, deixa de ser privilexio duns poucos, xa que pode entendela e practicala todo o mundo, feito que lles agradaba moito ás autoridades liberais que gobernaban naquel momento e, polo tanto, fomentaban e apoiaban estas iniciativas por se tratar dun movemento asociacionista liberal e pacífico 
que, indubidablemente, desenvolvía a intelixencia e a sensibilidade do pobo.

Estas asociacións, polo feito de reflectiren a agrupación de cidadáns que realizan actividades comúns, atópanse intimamente relacionadas coa liberdade de asociación e, polo tanto, os nomes de moitas bandas de música recollen esa idea con termos como "Unión”, "Unión Musical”, "Unión Artística” e moitos outros que se estenderon por toda Galicia. Isto tamén estivo motivado pola re-unión das distintas agrupacións que existían na vila ou parroquia, pois o repertorio oriéntase cara a bandas cun mínimo ideal de 35/40 músicos.

Así, no campo da música, a finais do século XIX aparecen en moitos lugares de Europa e, en particular en España, as asociacións de instrumentistas - as bandas populares - e as de cantantes - corais e orfeóns-, moitas delas constituídas por xente non profesional e outras por semiprofesionais. O fenómeno estendeuse por toda España e acadou cotas importantes en Cataluña e no País Vasco (orfeóns e corais) e no Levante español, principalmente Valencia (as bandas de música). En Galicia déronse simultaneamente os dous fenómenos, pero con menor importancia.

A Federación Galega de Bandas de Música Populares (FGBMP) nace en 1986 da man dun pequeno grupo de asociacións. Cos anos vai aumentando en compoñentes e na actualidade (xaneiro de 2021) está formada por 94 bandas de música populares que engloban a 6.262 federados. A súa distribución xeográfica por provincias é:

- A Coruña: 28

- Lugo: 9

- Ourense: 5

- Pontevedra: 52

Dende a FGBMP estímase que hai unhas 20 agrupacións non federadas. Unha parte delas ou ben teñen pouca actividade ou parte dos 
seus músicos actúan en formacións máis grandes para certames, festivais e outras actividades esporádicas.

Nos últimos anos está gañando cada vez máis peso o seu labor formativo, que desenvolven a través das escolas de música da propia asociación. Se ben hai anos os seus integrantes tiñan certa idade, na actualidade o maior peso concéntrase en músicos menores de 30 anos, polo que tamén cabe destacar a creación de seccións infantís e/ou xuvenís, ou ben directamente da banda infantil ou xuvenil da propia agrupación.

As dúas formacións máis antigas de Galicia son A Lira de Ribadavia e a Banda Artística de Merza(ambas da primeira metade do século XIX). Do século XIX continúan activas outras formacións como Unión de Guláns (Ponteareas), Unión de Lantaño (Portas), Airiños do Morrazo (Moaña) e as bandas de música de Sober, de Visantoña (Santiso), de Lobios ou de Castrelo (Cambados), entre outras. 
DOCUMENTOS DE TRABALLO

DOCUMENTOS DE TRABALLO

\section{Introdución}

As bandas de música populares en Galicia xorden como un fenómeno de socialización que se foi estendendo ao longo da xeografía galega e ampliando os seus ámbitos de actuación. O fenómeno atópase descrito nunha breve historiografía musical que se limita a un número reducido de estudos publicados nos últimos 30 anos¹.

Entre os autores máis salientables que escribiron artigos sobre as bandas de música destaca Rogelio Groba, sobranceiro compositor e director da Banda Municipal da Coruña entre 1967 e 1989, que escribiu un dos primeiros artigos que se coñecen sobre as bandas de música en Galicia $^{2}$. O traballo constitúe un eloxio das bandas de música como institucións cun enorme arraigamento popular, que desempeñaban un importantísimo papel de difusoras da cultura musical na sociedade rural galega. Reflexiona sobre a función orixinaria das bandas, ligada ás celebracións festivas de carácter relixioso, e sobre a función formativa que tiveron en ensinanzas prácticas da música. As bandas, así mesmo, supuxeron unha importante fonte de creación musical con grandes compositores de repertorios bandísticos. Por último, pon de relevo o papel de cohesión social que desempeñaban nos diversos eventos festivos das vilas e aldeas de Galicia.

En 1984, Xulio Cuns Lousa publicou un artigo en que realiza un estudo moi exhaustivo sobre a banda municipal de Betanzos ${ }^{3}$. Neste traballo comeza facendo un percorrido histórico sobre a música popular en España e en Galicia, para logo centrarse na historia da banda de música de Betanzos. Aborda aspectos como o ensino da música na Academia de Música Municipal, a vinculación estreita da banda de música nos actos festivos da vila e, polo tanto, a implicación directa do concello de Betanzos na contratación de músicos, da dirección da banda e da academia de música. Menciona o primeiro regulamento municipal polo que se debe

${ }^{1}$ Noche García, S. (2017): "Una aproximación a la historiografía musical sobre las agrupaciones bandísticas gallegas: el caso concreto de la Banda Municipal de Ourense”, Estudios Bandísticos, vol. I, pp. 109-166.

2 Groba, R. (1983): “Pasado y futuro de las bandas de música populares”, en II Homenaxe ás bandas populares de música de Galicia, Santiago de Compostela.

${ }^{3}$ Cuns Lousa, X. (1984): “La banda municipal de Betanzos en el siglo XIX”, Anuario Brigantino, no 7, pp. 137-150. 
rexer unha escola de música municipal, a sucesión de directores que tivo a banda ao longo do século XIX dende a súa creación e as dificultades económicas, políticas e administrativas que tivo que atravesar e que puido superar para non desaparecer.

Luís Costa Vázquez publicou en 1998 "La música popular” ${ }^{4}$ e, en 20135, “As bandas de música galegas: unha realidade inédita”, dous artigos en que fai unha descrición e revisión bibliográfica dos traballos de investigación e artigos publicados sobre as bandas de música populares de Galicia.

Por outra parte, de acordo con L. López Cobas $^{6}$, as bandas de música son un dos fenómenos de máis proxección social en España, especialmente nalgunhas rexións como a Comunidade Valenciana, pola cantidade de agrupacións que existen, ou Cataluña. En Galicia tamén hai un gran número de bandas de música. De feito, Enrique Iglesias Alvarellos ${ }^{7}$ documentou a existencia de 433 bandas de música en toda Galicia nalgún momento da historia, que foron pasando por diversas etapas de creación, desaparición, rexurdimento, transformación ou mesmo refundación.

A orixe das chamadas bandas civís foi por vontade popular e, de feito, a inmensa maioría están constituídas como asociacións culturais e co apoio das administracións locais principalmente. A súa función é, e foi dende o seu comezo, non só o ensino e a divulgación da música por parte de mestres de música tanto profesionais como afeccionados, senón tamén a de crear un espírito de asociacionismo no conxunto da comunidade local en que se crearon. Ao mesmo tempo que as bandas de música, creáronse tamén corais, rondallas, orfeóns e outro tipo de asociacións musicais que tiñan como función principal crear afección pola música en xeral. Ademais, no caso das bandas, desempeñaban tamén unha función social

\footnotetext{
${ }^{4}$ Costa Vázquez, L. (1998): “La música popular”, en Galicia. Antropología, vol. XXV, Hércules de Ediciones.

${ }^{5}$ Costa Vázquez L. (2013): “As bandas de música galegas: unha realidade inédita”, en M. Capelán / L. Costa Vázquez / J. Carballo Montalbes / C. Villanueva (eds.), Os soños da memoria. Documentación musical en Galicia: Metodoloxías para o estudio, Deputación de Pontevedra, pp. 341-362.

${ }^{6}$ López Cobas, L. (2008): "Las bandas de música en Galicia: Aproximación al caso de la ciudad de La Coruña en el siglo XIX”, Revista de Musicología, 31:1, pp. 79-123.

${ }^{7}$ Iglesias Alvarellos, E. (1986): Bandas de Música de Galicia, Alvarellos.
} 
DOCUMENTOS DE TRABALLO

DOCUMENTOS DE TRABALLO

nas vilas, porque eran numerosas as actuacións que tiñan nas festas, así como ruadas por diferentes motivos, como o acompañamento nas procesións das festas patronais ou nas de Semana Santa, por exemplo.

Tal como suxire Luís $\operatorname{Costa}^{8}$, a realidade actual das bandas de música populares de Galicia mudou moito. Hoxe en día a actividade das bandas populares ampliouse moito co fin de mellorar e dignificar a interpretación e composición musical mediante a celebración regular e crecente de festivais e certames competitivos que deron como resultado unha mellora salientable no nivel formativo e técnico, tanto de intérpretes como de directores. A isto contribuíu, en boa medida, a implantación das ensinanzas oficiais de música nas sete grandes cidades e nalgunhas vilas espalladas por toda Galicia nos conservatorios de música.

Como se verá ao longo deste informe, as bandas de música populares están moi vinculadas coas ensinanzas musicais. Aínda que no sistema educativo galego o ensino musical está presente na educación xeral, é no ensino especializado onde a práctica musical se sitúa como obxectivo principal, formación que se impartiu tradicionalmente nos conservatorios de música.

En Galicia, segundo datos da Consellería de Cultura, Educación e Universidades $^{9}$, hai un total de 36 conservatorios de música, dos cales 13 se atopan na provincia de Pontevedra, 12 na da Coruña, 7 na de Ourense e 4 na de Lugo. Destes, 3 imparten ensinanzas de grao elemental, 2 ensinanzas de grao superior e os 31 restantes ensinanzas de grao profesional. En todas as grandes cidades hai polo menos un conservatorio profesional e nas cidades de Vigo e da Coruña, un conservatorio superior. $\mathrm{O}$ resto dos conservatorios profesionais atópanse en vilas que son capitais de concello cunha poboación que vai dende os 5.000 aos 30.000 habitantes. En total, as ensinanzas regradas da música están dispoñibles para o 53,9\% da poboación galega.

A partir de 1990, coa entrada en vigor da Lei orgánica de ordenación xeral do sistema educativo (LOXSE) regúlase un novo tipo de centro para a

8 Costa Vázquez, L. (2013): op. cit.

9 Xunta de Galicia. Consellería de Cultura, Educación e Universidades: Base de datos de Centros Educativos (https://www.edu.xunta.gal/centroseducativos/BuscaCentros.do) (consulta: 4 de maio de 2021). 
educación musical especializada, as escolas de música, que se desenvolven no ámbito estatal na Orde do 30 de xullo de 1992, pola que se regulan as condicións de creación e funcionamento das escolas de música e danza (BOE n.o 202/1992, do 22 de agosto). No ámbito autonómico están reguladas pola Orde do 11 de marzo de 1993, pola que se regulan as condicións de creación e funcionamento das escolas de música e danza da comunidade autónoma de Galicia (DOG n.․75/1993, do 22 de abril).

Estes centros de educación musical non regrada teñen pouca tradición en Galicia. Non é o mesmo caso no resto de Europa, onde se crearon entidades homologables arredor dos anos 50 do pasado século, que se constituíron en centros de ensino que achegan a música a persoas de todas as idades, cuxo obxectivo principal é formar afeccionados á música, fundamentalmente a través da práctica, ben sexa instrumental ou vocal, e que dan cabida a manifestacións musicais variadas, incluídos a música e instrumentos musicais de distintas culturas e estilos diversos.

Contribuíu de forma especial á formación musical a creación das escolas municipais de música (ESMU), que, aínda que non imparten ensinanzas regradas, si contribúen de maneira salientable á formación práctica no ensino da música. Estas escolas de música de titularidade pública dependen, na maioría dos casos, dos concellos. En Galicia hai un total de 78 ESMU: 24 na provincia de Pontevedra, 23 na da Coruña, 21 na de Lugo e 10 na de Ourense. Hai concellos que teñen tanto conservatorio como escola municipal de música.

As escolas municipais de música e danza créanse coa finalidade de formar afeccionados ${ }^{10}$ xa que posibilitan unha organización flexible e adaptada ás posibilidades e recursos das entidades locais e ás características propias de cada lugar. En definitiva, estas escolas configúranse como centros formativos e de difusión cultural de gran calado e excelente acollida entre a poboación.

Na actualidade as escolas de música están integradas plenamente no sistema educativo e na sociedade e son capaces de responder e de adaptarse ás pretensións e demandas que a cidadanía ten no ámbito da

\footnotetext{
${ }^{10}$ Federación Española de Municipios y Provincias (2008): Guía del Concejal de Educación, p. 153.
} 
educación musical. Atenden as inquedanzas e desexos de formación permanente das persoas, que poden verse tamén satisfeitas a través dunha educación musical accesible a toda a poboación. Ademais, son centros que, dende o ámbito da educación non formal e dende a súa incardinación no marco do municipio, asumen a identidade cultural do seu contorno e convértense en focos de dinamización cultural deste.

En cifras globais, pódese dicir que en Galicia hai 5 escolas de música de titularidade pública (incluídos conservatorios e escolas municipais) por cada 100.000 habitantes, que cobren a un 70\% da poboación. No conxunto de España, esta cifra chega a 2,5 escolas de música por 100.000 habitantes ${ }^{11}$. Este dato cobra máis relevancia cando se ten en conta que Galicia ocupa o segundo lugar neste indicador, se se compara co conxunto das comunidades autónomas.

Outro dato interesante refírese á cifra de alumnado matriculado nas ensinanzas da música. Segundo as estatísticas do Ministerio de Educación y Formación Profesional, no curso 2019-2020 en Galicia había un total de 18.408 persoas matriculadas en ensinanzas de música en centros de titularidade pública. Destes, o 60\% estaba matriculado en escolas de música que imparten ensinanzas non regradas. A cifra total de alumnado matriculado en centros públicos de ensinanzas da música en Galicia supón un 9,8\% do total do alumnado matriculado no conxunto de España.

É neste contexto de ensino non regrado da música no que se encadran as bandas de música. Aínda que moitas das bandas de música populares de Galicia están constituídas como asociacións e teñen as súas propias escolas de música, tamén é certo que moitos dos seus músicos se forman na práctica instrumental nestas escolas municipais.

A importancia do ensino da música para as bandas de música de Galicia vese reflectido nun documento titulado "Declaración de Santiago de Compostela pola Música e a Educación Musical” ${ }^{12}$, que foi aprobado nun

\footnotetext{
${ }^{11}$ Ministerio de Educación y Formación Profesional. Subdirección General de Estadística y Estudios: Estadística de Enseñanzas no universitarias. Centros y servicios educativos. Curso 2019-2020.

12 “Declaración de Santiago de Compostela por la Música y la Educación Musical”, en Xornadas A Música no Século 21. A Banda no Camiño, Santiago de Compostela, 12 de maio de 2018.
} 
encontro que tivo lugar o 12 de maio de 2018 co gallo da celebración do 170 aniversario da banda municipal de música de Santiago de Compostela. Con respecto á educación musical, destácase a importancia do valor da música para a saúde e o benestar das persoas, tanto individual como colectivamente. A educación musical constitúe un dereito que debería integrarse nos niveis educativos, tanto en centros educativos do sistema obrigatorio, como en ensinanzas de réxime especial e superiores.

Tamén se menciona explicitamente a importancia das bandas de música e a necesidade de poñer en práctica ferramentas de apoio para a xestión das bandas de música en Galicia. En primeiro lugar, reivindícase o seu papel de cohesión social mediante a súa función e dimensión histórica, cultural e educativa e, polo tanto, a necesidade de dotar dun marco normativo as asociacións e a federación que lles serven de apoio. Ademais, saliéntase a tradición que precede as bandas de música en Galicia e o seu papel artístico fundamental tanto na creación e composición de obras musicais para banda, como na interpretación, dirección e innovación pedagóxica destas agrupacións. Para poder cumprir debidamente esta función artística e cultural tan importante, demándase un marco laboral axeitado tanto para os directores como para os músicos profesionais co fin de dignificar e pór en valor esta manifestación cultural tan importante en Galicia. Por último, maniféstase a necesidade de ofrecer unha formación específica de calidade e de crear un espazo de intercambio de experiencias musicais a través de encontros co fin de compartir coñecementos.

Este contexto é aplicable, en xeral, a todas as bandas de música en España, con lóxicas diferenzas territoriais, pero na esencia as características son as mesmas. Neste sentido, pódense atopar diversos traballos realizados sobre as sociedades musicais de forte arraigamento na Comunidade Valenciana ou en Cataluña. As bandas de música, ao teren un importante apego territorial de carácter fundamentalmente local, teñen presenza ao longo de toda a xeografía española e de aí que xurdisen numerosas asociacións de bandas de música ou sociedades musicais nos ámbitos estatal e das comunidades autónomas.

Nas comunidades autónomas de gran tradición bandística, existen traballos de investigación nos que se tratan aspectos históricos, 
sociolóxicos e de xestión económica e administrativa. ${ }^{13}$ Destes traballos pódese extraer a conclusión de que teñen unha estrutura organizativa moi elaborada e unhas agrupacións moito máis numerosas que en Galicia.

Cómpre, por último, destacar a Sociedade Española de Musicoloxía, que creou unha comisión de traballo dedicada exclusivamente ás bandas de música. Esta sociedade xustifica a creación deste grupo de traballo argumentando que:

Desde a súa orixe, as bandas de música estiveron fortemente vinculadas á súa comunidade de pertenza, coa que comparten multitude de vivencias, tanto sociais como musicais... A cara máis visible de todos estes procesos son os seus concertos de carácter público, así como a difusión do repertorio canónico ou a asunción de xéneros ás veces deostados pola vertente musical máis académica, como a zarzuela e a canción.

Todo isto fai da banda de música un obxecto de estudo extraordinariamente rico e interesante que é necesario pór en valor...

\section{Metodoloxía}

\subsection{Obxectivos}

O obxecto deste traballo é revisar as condicións actuais das bandas de música populares en Galicia e o papel de desenvolvemento cultural que realizan os integrantes das bandas, músicos, persoal directivo, docentes de música e a súa integración no contorno xeográfico e económico no que se

\footnotetext{
${ }^{13}$ Astruells Moreno, S. (2003): La Banda Municipal de Valencia y su aportación a la historia de la música valenciana, Universitat de València.

Ayala Herrerp, M. I. (2013): Música y municipio: Marco normativo y administración de las bandas civiles en España (1931-1986). Estudio en la provincia de Jaén, Universidad de Granada.

Alba Eguiluz, B. de (2015): Las escuelas de música del País Vasco. Análisis de una realidad educativa, Universidad del País vasco.

Gómez Asensio, D. (2014): La Gestión Cultural en las Sociedades Musicales de la Comunidad Valenciana. Hacia una Profesionalización de la Gestión Musical, Universitat Politèctica de València. Morant Navasquillo, R. (2012): Perspectivas docentes de las escuelas de música de las sociedades musicales valencianas: Historia, presente y futuro, Universitat Jaume I.
} 
integran, que en Galicia se adscribe a vilas onde hai un conservatorio ou unha escola municipal de música ou mesmo a pequenas aldeas nun contorno máis rural. Tamén se quere describir en que medida se viron afectadas polas condicións impostas pola pandemia da COVID-19 nas súas actividades cotiás.

\subsection{Cuestionario e mostra}

Este informe está baseado nas respostas a un cuestionario que se lle propuxo á Federación Galega de Bandas de Música Populares para que contestasen as bandas asociadas. Este instrumento incorporou preguntas suxeridas pola propia federación, un cuestionario incluído nun traballo de investigación sobre as sociedades musicais da Comunidade Valenciana ${ }^{14} \mathrm{e}$, para a segunda parte do traballo referida ás consecuencias da pandemia, tivéronse tamén en conta as preguntas en que se baseou o cuestionario dos barómetros da cultura galega ${ }^{15}$.

O primeiro dos traballos mencionados empregouse na primeira parte do cuestionario para describir o funcionamento e actividades das bandas de música, as asociacións en que están integradas e as escolas de música destas. Aínda que esta enquisa foi empregada como base houbo que reformulala para que se puidese adaptar ás circunstancias máis reais das bandas de música populares en Galicia. Cómpre ter en conta que non existe ningún estudo semellante exclusivo para Galicia ou, se existe, non está publicado. De todos os xeitos, o cuestionario foi sometido á supervisión da FGBMP para que achegase as súas suxestións sobre as preguntas formuladas na enquisa.

Os barómetros da cultura galega foron empregados como base para o deseño das preguntas para analizar o impacto da pandemia nas actividades presentes e futuras das bandas de música, nomeadamente as repercusións que tiveron que soportar como consecuencia da paralización case total da actividade. Tendo en conta que as bandas de música se

${ }^{14}$ Gómez Asensio, M.: La Gestión Cultural en las Sociedades Musicales de la Comunidad Valenciana. Hacia una Profesionalización de la Gestión Musical. Proxecto final do Máster Oficial Interuniversitario en Xestión Cultural (Curso 2013-2014). Universitat Politècnica de València.

${ }^{15}$ Observatorio da Cultura Galega (xaneiro de 2021): Barómetro da Cultura Galega II (http://consellodacultura.gal/publicacion.php?id=4398). 
DOCUMENTOS DE TRABALLO

DOCUMENTOS DE TRABALLO

atopan dentro das actividades do sector das artes escénicas e musicais, que foi o que resultou máis afectado por esta pandemia, quíxose indagar no cuestionario de que maneira concreta lles afectou á súa actividade ordinaria, tanto no que respecta ao funcionamento e xestión interna como á súa relación cos axentes externos que facilitan e fan posible as súas actividades, como poden ser as administracións das que dependen, ou ben a acollida dos seus concertos por parte do público.

Finalmente, deixouse dentro do cuestionario un espazo libre para que expresasen as súas propias opinións, suxestións e demandas, dado que se consideraba que a realidade das bandas era moi diferente e era previsible que algúns aspectos que se tratasen na enquisa non cubrisen cuestións que consideraban importantes.

O universo de estudo son as bandas de música asociadas á Federación Galega de Bandas de Música Populares. Das 94 entidades federadas contestaron 85 bandas. O cuestionario aplicouse de maneira telemática entre o 28 de abril e o 17 de maio de 2021. Os resultados supoñen unha explotación dunha selección das frecuencias das preguntas. En moitas ocasións procedeuse a recategorizar preguntas abertas e con respostas múltiples.

Non se fixeron análises de segmentación nin se definiron variables independentes, en parte polo relativamente escaso número de casos e tamén porque entre os obxectivos do estudo non estaba establecer análises comparativas entre as diferentes bandas de música, senón ofrecer unha visión de conxunto que cuantificase a dimensión social, educativa e profesional das bandas.

\subsection{Contidos do informe}

Tal e como se explica nos dous apartados anteriores, unha vez definidos os obxectivos do estudo, delimitado o universo das bandas de música obxecto de análise e seleccionadas as preguntas que debían conformar o cuestionario, o seguinte paso foi decidir o deseño da estrutura do informe, de forma que conseguise describir en profundidade a situación actual destas agrupacións, as súas singularidades, eivas e desafíos e tamén as súas inquedanzas cara ao porvir por mor da crise pandémica. 
O corpo e contido do estudo xiran arredor da dimensión social das bandas de música populares en Galicia e ordénase do seguinte xeito: en primeiro lugar expóñense os datos xerais destas entidades musicais, como ano de fundación, número de socios, persoas que integran a xunta directiva, así como agrupacións ou seccións que as compoñen. En segundo lugar abórdanse as características dos seus intérpretes, tipo de instrumento que tocan, número de intérpretes por cada sección musical e tipo de ensinanza que recibiron.

A dirección das bandas é outro dos apartados do informe. O número de directores e directoras das distintas agrupacións ou seccións, os anos de antigüidade no desenvolvemento desta función, o tipo de contrato que teñen, o número de horas da súa xornada laboral, así como a clase de formación especializada que posúen. Un dos apartados máis extensos deste traballo de investigación é o referido ás escolas de música das bandas. Céntrase fundamentalmente no número de alumnos/-as segundo materias e especialidades impartidas na escola, a procedencia académica do alumnado, o sexo ou a súa franxa de idade. Tamén se analizan as propias escolas e a valoración que as bandas enquisadas teñen destas.

A xestión das bandas de música populares dá conta do tipo de persoal contratado polas asociacións para esta ocupación: dirección, profesorado, persoal administrativo, persoal directivo etc. Neste eido indágase sobre quen son as persoas responsables da elaboración do programa xeral de actividades da banda e/ou a escola de música e tamén se inclúe unha avaliación da calidade do equipamento das infraestruturas das bandas.

Tras a sección dedicada á xestión, estúdase a actividade desenvolvida polas bandas: lugar onde adoitan actuar e motivo das súas actuacións, recintos en que realizan os seus concertos, así como o tipo de axente, institución, entidade etc. que as contrata. A análise tamén se detén nas actividades complementarias ou colaboracións con outras entidades que levan a cabo as asociacións.

No sétimo apartado abórdanse as fontes de financiamento das bandas de música: subvencións públicas, cotas de socios, honorarios, patrocinios etc. e os seus ingresos anuais. 
O público é outro dos títulos do informe e recolle fundamentalmente a asistencia media de espectadores e o tipo de público.

O capítulo sobre a difusión e imaxe das bandas ofrece información sobre as ferramentas de comunicación máis utilizadas para difundir as súas actividades e comunicarse cos seus membros e tamén cos seus espectadores, así como o tipo de estratexias que deseñan para fidelizar e captar novos públicos, afianzar ou mellorar a súa imaxe pública e coñecer as opinións e suxestións do alumnado, profesorado ou público, co fin de mellorar e adaptarse ás necesidades expostas.

Por último, estúdase a incidencia da COVID-19 nas bandas de música, centrada en aspectos como cuestións laborais do cadro de persoal, o financiamento das actividades, dificultades que tiveron que afrontar na súa actividade regular por mor das medidas de restrición impostas e a reacción do público como consecuencia dos cambios que tiveron que aplicar.

\section{A dimensión social das bandas de música populares en Galicia}

\subsection{Datos xerais das entidades}

As bandas de música populares galegas teñen unha antigüidade media de 61 anos. A banda máis antiga das que participaron na enquisa constituíuse en 1828 e a máis recente no ano 2015. O groso das bandas galegas, case a metade (46,9\%), fundouse entre 1975 e 1999, un 21\% antes de 1899, un 12,3\% entre 1900 e 1974 e un 19,8\% de 2000 en diante. Máis da metade destas agrupacións mantiveron unha actividade ininterrompida dende a súa creación. 


\section{Ano de fundación da entidade}

\begin{tabular}{lrr} 
Ano de fundación & N & Porcentaxe \\
\hline Ata 1899 & 17 & 21,0 \\
De 1900 a 1949 & 7 & 8,6 \\
De 1950 a 1974 & 3 & 3,7 \\
De 1975 a 1999 & 38 & 46,9 \\
De 2000 en diante & 16 & 19,8 \\
Ns/nc & 4 & 5,9 \\
Total & 85 & 100,0 \\
\hline
\end{tabular}

Fonte: Elaboración propia

Na maior parte dos casos $(58,2 \%)$, as bandas que contestaron a enquisa son as únicas que hai no concello onde desenvolven a súa actividade. Con todo, é significativa a porcentaxe de bandas que coexisten con outra banda no mesmo concello (30,4\%). Ademais deste tipo de agrupacións musicais, nalgúns casos tamén coinciden no mesmo concello con entidades asociativas que xestionan coros, comparsas ou similares $(11,4 \%)$.

DOCUMENTOS DE TRABALLO

En relación co número de socias ou socios vinculados ás bandas, os índices porcentuais son bastante próximos entre aquelas que teñen entre 50 e 99 socios (un 28,9\%) e as que contan con 200 ou máis (26,3\%) e entre 100 e 199 (25\%). Por debaixo do 20\% sitúanse as de menos de 50.0 número oscila entre 15 nas máis modestas e ata 285 nas de maior envergadura, cunha media duns 85 membros. Do total de persoas asociadas, un $47,1 \%$ son mulleres

Persoas socias coas que conta aproximadamente a asociación na actualidade

\begin{tabular}{lr} 
Número de socios & Porcentaxe \\
\hline Menos de 50 & 19,7 \\
De 50 a 99 & 28,9 \\
De 100 a 199 & 25,0 \\
200 ou máis & 26,3 \\
Total & 100,0 \\
\hline
\end{tabular}

Fonte: Elaboración propia

O 88,6\% conta cunha xunta directiva de entre cinco e dez membros, un $6,3 \%$ ten menos de cinco e tan só un $4 \%$ ten máis de dez. Un $82,5 \%$ destes órganos de dirección está integrado por entre unha e cinco 
mulleres, o 11,3\% entre 6 e 9 mulleres e un 6,3\% non conta con ningunha. Do total de membros das xuntas directivas das bandas populares de música galegas (585), un 45,5\% son mulleres.

Número de persoas que compoñen a xunta directi
\begin{tabular}{lr} 
Membros & Porcentaxe \\
\hline Menos de 5 & 6,3 \\
De 5 a 10 & 88,6 \\
Más de 10 & 4,0 \\
\hline \multicolumn{2}{c}{ Fonte: Elaboración propia }
\end{tabular}

Un total de 7.010 persoas integran as diferentes agrupacións musicais galegas entrevistadas. Na maior parte dos casos as bandas están conformadas por distintas agrupacións ou seccións. Como se pode observar na seguinte táboa, as bandas de música son as maioritarias cun $61,8 \%$ do total, seguidas polas bandas xuvenís $(21,6 \%)$ e as bandas infantís $(13,5 \%)$.

\begin{tabular}{lrr} 
Agrupacións ou seccións & $\mathrm{N}$ & Porcentaxe \\
\hline & 4.33 & \\
Banda de música & 1 & 61,8 \\
Banda xuvenil & 1.512 & 21,6 \\
Banda infantil & 945 & 13,5 \\
Grandes bandas & 114 & 1,6 \\
Coro/Coral & 419 & 6,0 \\
Orquestra de corda & 120 & 1,7 \\
Cuartetos, quintetos e outras modalidades de grupos & 232 & 3,3 \\
reducidos & 272 & 3,9 \\
Outras & & \\
\hline
\end{tabular}

Fonte: Elaboración propia

Ademais, hai 83 bandas de música populares que contan cun total de 546 músicos que se dedican de forma profesional á música, mais que continúan a colaborar coas bandas populares, 6,6 de media por banda. Un $13,3 \%$ das bandas galegas estudadas non conta con ningún músico profesional e un $65,1 \%$ ten entre 1 e 10. 


\subsection{Características dos intérpretes}

Na seguinte táboa detállase o número de intérpretes por instrumento que integran as bandas de música. Do total de instrumentistas contabilizados, un 22,2\% son clarinetistas, seguidos dos percusionistas, que conforman o $10 \%$ dos instrumentistas das bandas.

Por seccións, obsérvase na seguinte táboa que son os integrantes da sección vento-madeira os que conforman máis da metade dos integrantes das bandas de música, concretamente un 55,8\%, seguidos dos da sección de vento-metal, que suman o 31,5\% dos intérpretes.

\section{Número de intérpretes por seccións}

\begin{tabular}{lr} 
Seccións & Porcentaxe \\
\hline VENTO-MADEIRA & $\mathbf{5 5 , 8}$ \\
Clarinete & 22,2 \\
Saxofón alto & 9,5 \\
Frauta & 8,7 \\
Saxofón tenor & 4,3 \\
Óboe & 2,7 \\
Fagot & 1,8 \\
Clarinete baixo & 1,7 \\
Frautín & 1,6 \\
Saxofón barítono & 1,5 \\
Saxofón soprano & 0,8 \\
Requinto & 0,7 \\
Corno inglés & 0,3 \\
\hline VENTO-METAL & $\mathbf{3 1 , 5}$ \\
\hline Trompeta & 9,8 \\
Trompa & 6,3 \\
Trombón & 6,0 \\
Tuba & 4,0 \\
Bombardino & 3,4 \\
Fliscorno/Fliscornio & 1,3 \\
Trombón baixo & 0,7 \\
\hline PERCUSIÓN & $\mathbf{1 0 , 0}$ \\
Percusión sinfónica & 10,0 \\
\hline CORDA & $\mathbf{2 , 7}$ \\
Violonchelo & 1,9 \\
Contrabaixo & 0,8
\end{tabular}

Fonte: Elaboración propia 
Un aspecto que se analizou nesta enquisa foi a formación musical que teñen os integrantes das bandas de música de Galicia. A formación musical en Galicia pode ser adquirida tanto no ensino regrado da música, que se estuda nos conservatorios, como no ensino non regrado, que se imparte tanto en escolas municipais de música de titularidade pública como en escolas privadas dependentes das asociacións ás que pertencen as bandas ou en calquera outro tipo de escola de música. Por este motivo, considerouse importante coñecer o tipo de formación musical especializada dos compoñentes das agrupacións musicais.

Para comezar, no que atinxe ás ensinanzas regradas da música, nas bandas enquisadas, 1.701 dos seus compoñentes estudan algún tipo de ensino regrado da música. En concreto, o $24,5 \%$ son estudantes do grao elemental de música, o $58,7 \%$ do grao profesional e o $16,8 \%$ do grao superior.

Máis salientable aínda é saber cantos dos compoñentes das bandas están en posesión dalgún título de ensinanzas regradas da música. En total, a cifra de músicos integrantes das bandas que contan con algún tipo titulación de estudos regrados da música ascende a 2.198 persoas. Neste caso, o 71,8\% das bandas de música obxecto deste informe conta con músicos que posúen titulacións oficiais de música.

Os integrantes das bandas de música con formación en ensinanzas non regradas da música reciben o ensino en escolas municipais de música de titularidade pública, en escolas de música privadas ou ben nos dous tipos de escolas.

A cifra total de músicos con este tipo de formación é de 2.406 persoas, das cales o 46,6\% estuda en escolas municipais de música e o $53,5 \%$ en escolas privadas. 0 71,4\% das bandas de música teñen algún integrante que está estudando en escolas de música municipais e un 79\% en escolas de música privadas. Neste sentido, cómpre salientar a influencia da formación que reciben os músicos nas escolas das asociacións, xa que 8 de cada 10 bandas contan con músicos que continúan a se formar musicalmente. 


\subsection{A dirección das bandas}

As bandas de música, ademais de ter o/a director/a principal, tamén poden ter directores/as de agrupacións menores. De feito, un 41,2\% das asociacións en que se integran as bandas ten máis dun director/a. Neste enquisa contabilizáronse un total de 141 directores/as entre os que desempeñan este cargo noutras agrupacións ou seccións.

Na seguinte táboa pódese observar que un 58,8\% das bandas ten só un director/a da banda principal, un $24,7 \%$ ten dous e un $16,5 \%$ máis de dous.

\begin{tabular}{|c|c|c|}
\hline \multicolumn{3}{|c|}{ № de directores/as entre as distintas agrupacións/secci } \\
\hline № de directores/as & $\mathrm{N}$ & Porcentaxe \\
\hline 1 & 50 & 58,8 \\
\hline 2 & 21 & 24,7 \\
\hline 3 ou máis & 14 & 16,5 \\
\hline Total & 85 & 100,0 \\
\hline
\end{tabular}

No que respecta á dirección actual da banda principal, observouse que o 44\% dos directores/as das bandas leva exercendo esta función de dirección non máis de 5 anos, mentres que 10,7\% leva no cargo máis de 20 anos. A antigüidade media na dirección da banda principal é de 9,7 anos.

Anos de antiguiidade do director/a actual da banda princi
\begin{tabular}{lcr} 
Anos de antigüidade & $\mathrm{N}$ & Porcentaxe \\
\hline Entre 0 e 5 & 37 & 44,0 \\
Entre 6 e 10 & 16 & 19,0 \\
Entre 11 e 15 & 11 & 13,1 \\
Entre 16 e 20 & 11 & 13,1 \\
Máis de 20 & 9 & 10,7
\end{tabular}
Fonte: Elaboración propia

Con respecto á relación laboral que ten a persoa que exerce a dirección principal da banda coa entidade, dominan os contratos indefinidos, xa que un 35,7\% están contratados mediante esta modalidade. Tan só un 3,6\% dos directores/as teñen un contrato fixo descontinuo. 
Tipo de contrato do director/-a da banda principal

\begin{tabular}{lrr} 
Tipo de contrato & N & Porcentaxe \\
\hline Autónomo/Por conta propia & 16 & 19,0 \\
Contrato fixo descontinuo & 3 & 3,6 \\
Contrato indefinido & 30 & 35,7 \\
Contrato temporal & 12 & 14,3 \\
Outra modalidade de contrato & 23 & 27,4 \\
Total & 84 & 100,0 \\
\hline
\end{tabular}

Fonte: Elaboración propia

A xornada laboral semanal das persoas que exercen a dirección das bandas varía entre unha e 40 horas segundo o caso, aínda que domina unha xornada laboral de entre 6 e 10 horas, que é a que teñen un 39,5\% dos directores/-as das bandas. A media de horas semanais traballadas é de 11,8 .

\begin{tabular}{lcr} 
& Xornada laboral semanal \\
№ de horas & $\mathrm{N}$ & $\%$ \\
\hline Entre 1 e 5 & 26 & 32,1 \\
Entre 6 e 10 & 32 & 39,5 \\
Entre 11 e 15 & 5 & 6,2 \\
Entre 16 e 20 & 4 & 4,9 \\
Máis de 20 & 14 & 17,3 \\
\hline & Fonte: Elaboración propia
\end{tabular}

Con respecto á formación das persoas que exercen a dirección da banda principal, cómpre ter en conta que nalgúns casos menciónanse máis dun tipo de formación. Con respecto á formación xeral, o 55,3\% dos directores/as das bandas posúe titulación superior en ensinanzas regradas da música ou equivalente e tamén hai algún caso de titulacións de posgrao.

En canto á formación especializada, menciónase sobre todo a de dirección de banda ou orquestra (32,9\%). Este tipo de formación especializada resulta moi variada porque hai casos tanto de formación en dirección de banda ou orquestra como especialización do Grao Superior de Música (cómpre lembrar que esta especialidade formativa se oferta no Conservatorio Superior da Coruña).

Tamén convén sinalar que hai varios casos de persoas que mencionan como formación especializada en dirección de banda a 
impartida na Escola Galega de Dirección de Bandas de Música. Esta escola creouse por iniciativa da Agrupación Musical da Limia e comezou a impartir o diploma de Iniciación á Dirección de Banda de Música no curso 2017-2018 en Ourense. No curso 2018-2019 impartíronse tamén os cursos de Perfeccionamento á Dirección de Banda de Música e de Xestión de Bandas de Música Populares.

Por último, tamén se mencionan outros tipos de formación especializada en dirección de banda ou orquestra, principalmente fóra de España. En canto á especialización instrumental, a maioría son clarinetistas, seguido de trompetistas e saxofonistas.

\section{Formación especializada dos directores/as da banda principal}

\begin{tabular}{llr} 
& & Porcentaxe \\
\hline \multirow{2}{*}{ Formación xeral } & Grao Profesional de ensinanzas regradas da música & 2,4 \\
& Grao Superior de ensinanzas regradas da música ou & \\
& equivalente & 55,3 \\
\hline Especializacións & Dirección de banda/orquestra & 32,9 \\
& Composición musical & 3,5 \\
& Outros & 2,4 \\
\hline & Clarinete & 12,9 \\
Especialización & Saxofón & 4,7 \\
instrumental & Trombón & 2,4 \\
& Trompeta & 7,1 \\
\cline { 2 - 3 } & Outros & 7,2 \\
\hline Cursos de especialización sen especificar & 3,5 \\
Sen estudos/ns/nc & 15,3 \\
\hline
\end{tabular}

Fonte: Elaboración propia

Como xa se mencionou anteriormente, hai asociacións en que, ademais da banda principal, se integran outras agrupacións ou sección cos seus respectivos directores/as. Este segundo responsable dirixe principalmente as bandas infantil e/ou xuvenil (un 51,9\% dos casos en que se conta con más dun director), seguidos dos directores/as de coral (11,1\%). Os subdirectores supoñen o 22,2\% destes cargos. 


Agrupacións que teñen un segundo director/a
Porcentaxe

O perfil destes segundos directores é de persoas cunha media de 7,7 anos de antigüidade no cargo, un $32 \%$ traballan cun contrato indefinido e cunha xornada laboral media de 6,5 horas semanais. Como formación específica, o 48,1\% teñen estudos de grao superior e o $44,4 \%$ son instrumentistas.

Aquelas asociacións que teñen un terceiro director ascenden a 9, que se distribúen nas seguintes agrupacións:

\begin{tabular}{lc} 
Agrupacións que teñen un terceiro director/a \\
N \\
Big Band & 2 \\
Banda xuvenil & 2 \\
Coral & 3 \\
Outras & 2 \\
\multicolumn{2}{|c}{ Fonte: Elaboración propia }
\end{tabular}

Os/as directores/as destas agrupacións teñen unha media de 5,5 anos de antigüidade no cargo. As oito persoas que están contratadas teñen un contrato indefinido ou outro tipo de contrato, cunha xornada laboral media de 9,4 horas semanais. A formación específica neste caso é máis variada.

Por último, hai 4 asociacións que teñen un cuarto director. A antigüidade media no cargo de director/-a é de cinco anos, traballan cun contrato sen especificar e súa xornada laboral media é de 6,3 horas 
semanais. En canto á súa formación, dominan as persoas que teñen estudos superiores de música.

\subsection{As escolas de musica das bandas}

Un 71,4\% das bandas de música galegas enquisadas dispoñen de escola de música asociada. 0 38,2\% destas escolas conta cunha antigüidade de entre 21 e 30 anos, o 27,3\% entre 31 e 50 anos, o 18,2\% entre 11 e 20 anos e un $16,4 \%$ entre 1 e 10 anos. A educación musical, a raíz destes datos, é un servizo ben implantado na maior parte das bandas galegas investigadas, xa que o 65,5\% ten escolas musicais cunha antigüidade de entre 21 e 50 anos.

As escolas de música das bandas galegas poden ser de titularidade pública, privada ou mixta (público-privada). Un 40\% destas escolas é de titularidade privada, un 14,1\% de titularidade pública municipal, un 8,2\% de titularidade público-privada e un 4,7\% de titularidade pública autonómica.

\begin{tabular}{|c|c|c|}
\hline & $\mathrm{N}$ & Porcentaxe \\
\hline Música e movemento & 1.177 & 16,5 \\
\hline Iniciación a instrumento & 1.598 & 22,5 \\
\hline Tecnoloxía e notación musical & 212 & 3,0 \\
\hline Linguaxe musical & 3.621 & 50,9 \\
\hline Teoría da música & 1.913 & 26,9 \\
\hline Educación auditiva & 1.817 & 25,5 \\
\hline
\end{tabular}

Fonte: Elaboración propia

Unha das cuestións formuladas ás bandas de música que participan neste estudo ten que ver coa escola de procedencia dos músicos que a integran. No caso de que haxa varias escolas no concello, o 60,4\% das bandas enquisadas están formadas por alumnos ou alumnas que proceden das propias escolas da asociación á que pertence a banda. $\mathrm{O}$ $30,2 \%$ nútrese das escolas municipais de música e tan só un 9,4\% conta con alumnado dos conservatorios.

No curso actual (2020-2021) asisten un total de 7.114 alumnos/-as ás escolas de música das bandas analizadas, dos cales un $50,7 \%$ son mulleres. 
A franxa de idade do alumnado abrangue entre os 8 e os 30 anos, aínda que un 91,9\% é menor de idade (entre 8 e 17 anos). O restante 8,1\% está conformado por alumnos e alumnas de entre 18 e 30 anos.

Practicamente a totalidade das escolas de música imparten as materias de "Música e movemento", "Iniciación a instrumento" e “Linguaxe musical”. “Tecnoloxía e notación musical” é a especialidade ofertada por un menor número de escolas (18 das 60 estudadas).

$\begin{gathered}\text { Escolas de música segundo as materias e especialidades que imparten } \\
\text { Materias/especialidades }\end{gathered}$
\begin{tabular}{lr} 
Música e movemento & 59 \\
Iniciación a instrumento & 59 \\
Tecnoloxía e notación musical & 18 \\
Linguaxe musical & 60 \\
Teoría da música & 39 \\
Educación auditiva & 38 \\
\hline \multicolumn{2}{c}{ Fonte: Elaboración propia }
\end{tabular}

Do total do alumnado, máis da metade (un 50,9\%) está matriculado en "Linguaxe musical”, un 26,9\% en "Teoría da música” e un 25,5\% en “Educación auditiva”. Só 212 alumnos/as do total reciben clases de “Tecnoloxía e notación musical”.

Algunhas das cuestións formuladas ás bandas de música para a elaboración deste estudo están relacionadas coa valoración de diferentes aspectos das escolas de música, entre os que se analizan instalacións, flexibilidade de horarios, nivel formativo, abano de especialidades, métodos de ensino, ratio profesorado/alumno, atención do profesorado, organización de actividades, material didáctico empregado, dispoñibilidade de instrumentos para o alumnado, xestión da escola e organización xeral.

Para o 90,8\% das bandas populares a atención do profesorado obtén unha valoración moi positiva: un 63,1\% considéraa moi boa e un $27,7 \%$ boa, seguida polo nivel formativo da escola e pola ratio profesorado/ alumno. No primeiro caso, un $86,2 \%$ outórgalle unha valoración moi boa ou boa e no segundo caso un $83,1 \%$. Os métodos de ensino, a xestión da escola, a organización de actividades, a organización xeral e a flexibilidade 
de horarios tamén son avaliados positivamente por máis do 70\% das bandas de música.

O aspecto peor valorado polas bandas ten que ver coas instalacións das escolas. Aínda que algo máis da metade as considera boas ou moi boas, un $28,8 \%$ cre que son malas ou regulares. Algo similar sucede coa dispoñibilidade de instrumentos cos que conta o alumnado, xa que un $21,5 \%$ das bandas enquisadas estima que é regular, mala ou moi mala. Semella que a valoración negativa tanto nas instalacións como a dispoñibilidade de instrumentos pode ter a súa xustificación no feito de que son recursos que precisan dun forte investimento, do que non dispoñen moitas bandas de música.

A seguinte táboa dá conta polo miúdo das diferentes valoracións.

DOCUMENTOS DE TRABALLO CCG

Valoración das bandas de diferentes aspectos relacionados coa escola de música

\begin{tabular}{lrrrrrr} 
& Moi boa & Boa & Axeitada & Regular & Mala & Moi mala \\
\hline Instalacións & 21,2 & 30,3 & 18,2 & 21,2 & 7,6 & 1,5 \\
Flexibilidade de horarios & 29,2 & 41,5 & 21,5 & 4,6 & 3,1 & 0,0 \\
Nivel formativo & 38,5 & 47,7 & 12,3 & 1,5 & 0,0 & 0,0 \\
Abano de especialidades & 23,1 & 41,5 & 30,8 & 4,6 & 0,0 & 0,0 \\
Métodos de ensino & 29,2 & 49,2 & 18,5 & 3,1 & 0,0 & 0,0 \\
Ratio profesorado/alumno & 50,8 & 32,3 & 12,3 & 4,6 & 0,0 & 0,0 \\
Atención do profesorado & 63,1 & 27,7 & 6,2 & 3,1 & 0,0 & 0,0 \\
Organización de actividades & 32,8 & 42,2 & 14,1 & 10,9 & 0,0 & 0,0 \\
Material didáctico empregado & 20,0 & 46,2 & 26,2 & 7,7 & 0,0 & 0,0 \\
Dispoñibilidade de instrumentos & 29,2 & 23,1 & 26,2 & 13,8 & 6,2 & 1,5 \\
para o alumnado & 33,8 & 41,5 & 12,3 & 9,2 & 3,1 & 0,0 \\
Xestión da escola & 33,8 & 40,0 & 16,9 & 7,7 & 1,5 & 0,0 \\
Organización xeral & Fonte: Elaboración propia & & &
\end{tabular}

O estudo sondou tamén a opinión das bandas de música populares sobre a calidade do equipamento dispoñible nas súas propias infraestruturas: auditorio, salas de ensaio, equipo de gravación, oficina de administración, aulas, cabinas de estudo, arquivo de partituras, vehículo e instrumentos en propiedade. 
Para poder analizar este aspecto, hai que ter en conta que algunhas das bandas enquisadas carecen dalgunha das infraestruturas formuladas. Por exemplo, un 68,4\% destas non conta con equipo de gravación, un 64,1\% carece de vehículo propio (furgoneta ou camión), un 55\% non dispón de cabinas de estudo e un 35\% non ten auditorio. A valoración máis baixa por parte das bandas populares ten que ver sobre todo coas oficinas de administración, xa que un $37,5 \%$ as cualifica cun nivel baixo de calidade (só un $8,8 \%$ as considera de alta calidade). No caso das salas de ensaio, tamén se aprecia unha estimación moderada: un 37,5\% das bandas considera que a calidade destas é media e un 33,8\% baixa. As condicións dos instrumentos propiedade das bandas son avaliadas cun nivel medio polo 55\% destas agrupacións e baixo por un 23,8\%. A táboa que vai a continuación mostra a valoración das bandas sobre a calidade das nove infraestruturas analizadas.

\section{Valoración da calidade do equipamento e as infraestruturas de que dispón a banda} de música

\begin{tabular}{lrrrr} 
& Alto & Baixo & Medio & Non ten \\
\hline Auditorio & 27,5 & 13,8 & 23,8 & 35,0 \\
Salas de ensaio & 22,5 & 33,8 & 37,5 & 6,3 \\
Equipo de gravación & 2,5 & 17,7 & 11,4 & 68,4 \\
Oficina de administración & 8,8 & 37,5 & 36,3 & 17,5 \\
Aulas & 20,0 & 31,3 & 36,3 & 12,5 \\
Cabinas de estudo & 10,0 & 21,3 & 13,8 & 55,0 \\
Arquivo de partituras & 25,0 & 30,0 & 43,8 & 1,3 \\
Furgoneta/camión & 9,0 & 11,5 & 15,4 & 64,1 \\
Instrumentos en propiedade & 21,3 & 23,8 & 55,0 & 0,0 \\
\hline \multicolumn{4}{c}{ Fonte: Elaboración propia }
\end{tabular}

\subsection{Xestión das bandas}

En xeral, as asociacións en que están integradas as bandas de música teñen persoal contratado, concretamente o $83,5 \%$ das que contestaron o cuestionario. A seguinte táboa mostra as categorías de persoal contratado e obsérvase que un $67,1 \%$ das asociacións ten contratado o director/a da banda e un 55,3\% o profesorado da escola de música. Por último, cómpre apuntar que un 16,5\% das asociacións non ten ningún persoal contratado. 


\section{Persoal contratado polas asociacións}

\begin{tabular}{lrr} 
& N & Porcentaxe \\
\hline Director/-a da banda & 57 & 67,1 \\
Profesorado & 47 & 55,3 \\
Ningún & 14 & 16,5 \\
Persoal administrativo & 12 & 14,1 \\
Outros & 8 & 9,4 \\
Persoal de xestión & 7 & 8,2 \\
Persoal do equipo directivo & 3 & 3,5 \\
Total & 85 & 100,0 \\
\hline \multicolumn{3}{c}{} \\
\multicolumn{2}{c}{ Fonte: Elaboración propia }
\end{tabular}

Entre aquelas asociacións que si teñen persoal contratado, o 40,6\% ten ata 5 persoas contratadas e un $24,6 \%$ ten un cadro de persoal formado por entre 11 e 15 persoas. Tan só 3 asociacións teñen máis de 20 persoas contratadas.

\section{№ de persoas contratadas polas asociacións}

Porcenta

\begin{tabular}{lrr} 
& $\mathrm{N}$ & $\mathrm{xe}$ \\
\hline Entre 0 e 5 & 28 & 40,6 \\
Entre 6 e 10 & 13 & 18,8 \\
Entre 11 e 15 & 17 & 24,6 \\
Entre 16 e 20 & 8 & 11,6 \\
Máis de 20 & 3 & 4,2 \\
\hline
\end{tabular}

Tanto a xunta directiva como a dirección musical ou formativa das bandas de música populares son na maior parte dos casos as que deseñan a programación xeral das actividades destas $(75,3 \%$ e $71,8 \%$ respectivamente). Tamén se dá certa participación do profesorado e a administración, pero nunha porcentaxe moito máis baixa $(14,1 \%$ no primeiro caso e $12,9 \%$ no segundo), como se pode ver na táboa que vai a continuación. 
Persoas que realizan a programación xeral das actividades da banda e/ou escola de música

\begin{tabular}{lr} 
& Porcentax \\
\hline Xunta directiva & 75,3 \\
Persoal de xestión & 4,7 \\
Dirección musical/formativa & 71,8 \\
Profesorado & 14,1 \\
Administración & 12,9 \\
Outros $\quad 3,5$ \\
\hline \multicolumn{2}{c}{ Fonte: Elaboración propia }
\end{tabular}

\subsection{Actividade}

A propia vila ou concello ao que pertencen as bandas é o lugar onde estas adoitan realizar as súas actuacións cada ano, un 90,6\%. Un 51,8\% tamén acostuma actuar noutros concellos da provincia e un $47,1 \%$ nos da propia comarca. A porcentaxe de bandas que actúan fóra de Galicia (2,4\%) e incluso do país (3,5\%) é moi baixa.

Lugar onde adoitan realizar actuacións cada ano as bandas de música

\begin{tabular}{lr} 
Lugar & Porcentaxe \\
\hline Na propia vila ou concello & 90,6 \\
Noutros concellos da comarca & 47,1 \\
Noutros concellos da provincia & 51,8 \\
Noutros concellos de Galicia & 29,4 \\
Noutra comunidade autónoma & 2,4 \\
Noutro país & 3,5 \\
\hline
\end{tabular}

Fonte: Elaboración propia

Os actos festivos do concello ou vila á que pertencen as bandas son o motivo principal que promove a súa actividade, xa que realizan un $92,9 \%$ das súas actuacións na súa localidade. Isto podería deberse a que habitualmente as agrupacións asinan un convenio de colaboración co seu concello para poder desenvolver un determinado número de actividades. O 71,8\% son contratacións para concertos fóra do seu concello e o 70,6\% forma parte da programación estable destas agrupacións musicais. 


\section{Motivos polos que realizan actuacións}

Motivo

Porcentaxe

$\begin{array}{lr}\text { Programación estable da banda } & 70,6 \\ \text { Participación en actos festivos do concello ou vila } & 92,9 \\ \text { Contratacións para concertos fóra do concello } & 71,8 \\ \text { Certames ou concursos } & 43,5 \\ \text { Concertos extraordinarios (en datas especiais, con fins benéficos, en } & \\ \text { programas de televisión...) } & 38,8\end{array}$

Fonte: Elaboración propia

As comisións de festas e o propio concello onde están asentadas as bandas estudadas son os que se encargan da maior parte das súas contratacións (89,4\% e 82,4\% respectivamente). Os concellos doutras vilas ou cidades realizan máis da metade das contratacións destas agrupacións, seguidos polas deputacións provinciais e asociacións (un 48,2\% en ambos os dous casos).

Entidades que contratan as actuacións das bandas

\begin{tabular}{lr} 
& Porcentaxe \\
\hline O propio concello & 82,4 \\
Os concellos doutras vilas ou cidades & 58,8 \\
As deputacións provinciais & 48,2 \\
A AGADIC/Xunta de Galicia & 18,8 \\
Outros organismos oficiais & 7,1 \\
Asociacións & 48,2 \\
Comisións de festas & 89,4 \\
Outros & 7,1 \\
\hline \multicolumn{2}{c}{ Fonte: Elaboración propia }
\end{tabular}

Os auditorios son os recintos cubertos máis utilizados polas bandas para ofrecer os seus concertos (un $87,1 \%$ ), seguidos das igrexas, catedrais e mosteiros (40\%) e das salas de concertos (24,7\%). As salas de festas son o espazo menos utilizado, como se mostra na seguinte táboa. 


\section{Recintos cubertos onde adoitan realizar os seus concertos}

\begin{tabular}{lr} 
Recintos cubertos & Porcentaxe \\
\hline Salas de concertos & 24,7 \\
Teatros & 18,8 \\
Auditorios & 87,1 \\
Salas de festas & 3,5 \\
Instalacións cubertas permanentes ou & 32,9 \\
temporais & 40,0 \\
Igrexas, catedrais e mosteiros & 7,1 \\
Monumentos cubertos & 4,7 \\
Museos & 18,8 \\
Outros espazos cubertos &
\end{tabular}

Fonte: Elaboración propia

En canto aos recintos ao aire libre que utilizan as bandas de música para realizar os seus concertos, o 91,6\% das enquisadas adoita facelo nos espazos e prazas públicas, un 65,9\% nos parques e xardíns e un 64,7\% utiliza os palcos da música. Escenarios para orquestras e auditorios son lugares usados por menos do $20 \%$ destas bandas e só un $11,8 \%$ actúa en monumentos ao aire libre.

\begin{tabular}{|c|c|}
\hline \multicolumn{2}{|c|}{ Recintos ao aire libre nos que adoitan realizar os seus $c$} \\
\hline Recintos ao aire libre & Porcentaxe \\
\hline Auditorios & 29,4 \\
\hline Carpas & 55,3 \\
\hline Escenarios para orquestras & 20,0 \\
\hline Palcos da música & 64,7 \\
\hline Espazos e prazas públicas & 91,8 \\
\hline Parques e xardíns & 65,9 \\
\hline Monumentos ao aire libre & 11,8 \\
\hline
\end{tabular}

Fonte: Elaboración propia

Un número considerable das bandas de música adoita levar a cabo actividades complementarias ás actuacións musicais. Un 42,4\%, por exemplo, imparte clases maxistrais ou cursos de verán e un 4,2\% organiza campamentos instrumentais. Só un 14,1\% das agrupacións estudadas non realiza ningún tipo de actividade extra. 


\section{Actividades complementarias organizadas polas asociacións}

\begin{tabular}{lr} 
Actividades complementarias & Porcentaxe \\
\hline Clases maxistrais & 42,4 \\
Cursos de verán & 42,4 \\
Campamentos instrumentais & 41,2 \\
Obradoiros & 18,8 \\
Conferencias & 15,3 \\
Exposicións & 7,1 \\
Concursos & 20,0 \\
Ningunha & 14,1 \\
Outras & 24,7 \\
\hline
\end{tabular}

Fonte: Elaboración propia

Ademais da realización de actividades complementarias, as bandas de música enquisadas tamén levan a cabo nalgúns casos algún tipo de colaboración ou proxecto en conxunto con outras entidades, sobre todo intercambios con outras bandas de música (un 80\%). Así mesmo, as relacións con diferentes asociacións locais ou centros educativos favorecen a colaboración entre si: un $67,1 \%$ das bandas no primeiro caso e un $62,4 \%$ no segundo desenvolven esta clase de cooperación.

Colaboracións ou proxectos realizados con outras entidades

\begin{tabular}{lr} 
Colaboracións & Porcentaxe \\
\hline Colaboración en iniciativas da Federación Galega de Bandas de & 61,2 \\
Música Populares & 80,0 \\
Colaboracións ou intercambios con outras bandas de música & 67,1 \\
Colaboración con diferentes asociacións locais & 62,4 \\
Actividades en centros educativos & 5,9 \\
Pertenza a redes ou circuítos de auditorios & 4,7 \\
Participación en proxectos europeos & 2,4 \\
Ningún & 15,3 \\
Outro &
\end{tabular}

\subsection{Financiamento}

Neste apartado analízanse os medios de financiamento das bandas de música. Esta pregunta do cuestionario era de resposta múltiple, polo que se dá por suposto que as bandas de música usan diversas fontes para recadar ingresos. 
Como se pode observar na seguinte táboa, dos distintos instrumentos que empregan para poder soster as súas actividades, os principais son os honorarios por actuacións e as subvencións públicas, que nos dous casos acadan unha porcentaxe de resposta dun $85,9 \%$. A segunda fonte de financiamento que achega máis ingresos son as cotas de socios, nun 75,3\% dos casos. Os premios e as clases e cursos constitúen outras dúas importantes fontes de ingresos. Obsérvase tamén que 14 bandas de música reciben cartos procedentes de patrocinadores, o que supón un 16,5\% dos casos. Ademais, a venda de discos e artigos de merchandising supón en conxunto un $28,2 \%$ dos ingresos das bandas. Por último, é salientable o feito de que tan só un 2,4\% das bandas obtén ingresos por venda de entradas para os concertos, o cal implica que case a totalidade das actuacións das bandas de música son gratuítas.

\begin{tabular}{lrr}
\multicolumn{3}{c}{ Fontes de financiamento das bandas de música } \\
& $\mathrm{N}$ & Porcentaxe \\
\hline Caché por actuacións & 73 & $85,9 \%$ \\
Subvencións públicas & 73 & $85,9 \%$ \\
Cotas de socios & 64 & $75,3 \%$ \\
Premios & 24 & $28,2 \%$ \\
Clases e cursos & 23 & $27,1 \%$ \\
Venda de discos ou gravacións & 16 & $18,8 \%$ \\
Patrocinios & 14 & $16,5 \%$ \\
Outros & 13 & $15,3 \%$ \\
Artigos de merchandising & 8 & $9,4 \%$ \\
Billeteira & 2 & $2,4 \%$ \\
\hline \multicolumn{2}{c}{ Fonte: Elaboración propia } \\
\hline
\end{tabular}

No que atinxe aos ingresos anuais dos que dispoñen as bandas, cómpre salientar que, segundo os datos que se mostran na seguinte táboa, a maioría das bandas de música, un 63,4\%, obtén uns ingresos de ata 30.000 euros. Do restante $36,6 \%$, tan só un 9,8\% das bandas de música, que suman un total de oito, recibe ingresos superiores a 80.000 euros. 


\begin{tabular}{lrr}
\multicolumn{3}{c}{ Ingresos anuais das bandas de música } \\
Ingresos & $\mathrm{N}$ & Porcentaxe \\
\hline$<10.000$ euros & 23 & 28,0 \\
Entre 10.001-30.000 euros & 29 & 35,4 \\
Entre 30.001-50.000 euros & 12 & 14,6 \\
Entre 50.001-80.000 euros & 10 & 12,2 \\
Entre 80.001-100.000 euros & 5 & 6,1 \\
$>100.000$ euros & 3 & 3,7 \\
Total & 82 & 100,0 \\
\hline \multicolumn{2}{c}{}
\end{tabular}

\subsection{Público}

Para o 28,2\% das bandas de música, a asistencia media aos concertos é de entre 50 e 100 persoas. Un 18,8\% destas conta cunha media de entre 101 e 150 espectadores, por unha banda, e de 201 e 300, por outra, mentres que o 16,5\% das bandas acada unha media ou ben de entre 151 e 200 persoas ou ben de máis de 300, como se mostra na táboa que vai a continuación.

DOCUMENTOS DE TRABALLO CCG

\begin{tabular}{lr}
$\begin{array}{c}\text { Asistencia media de público aos concertos da banda } \\
\text { Asistencia media }\end{array}$ & $\begin{array}{r}\text { Porcentaxe } \\
\hline \text { Menos de 50 persoas }\end{array}$ \\
Entre 50 e 100 persoas & 28,2 \\
Entre 101 e 150 persoas & 18,8 \\
Entre 151 e 200 persoas & 16,5 \\
Entre 201 e 300 persoas & 18,8 \\
Máis de 300 persoas & 16,5 \\
\hline \multicolumn{2}{c}{ Fonte: Elaboración propia }
\end{tabular}

A idade é un indicador de grande influencia na frecuencia da asistencia aos concertos das bandas de música populares. Case un $59 \%$ das bandas conta sempre con público maior de 65 anos e un 37,6\% de xeito habitual. $O$ $57,6 \%$ destas agrupacións musicais recibe habitualmente a espectadores de entre 26 e 65 anos e, en menor medida, sempre (un 40\%, entre 41 e 65 anos e un 16,5\% na franxa de idade de entre 26 e 40). A frecuencia na asistencia aos concertos das bandas baixa canto menor idade teñen os espectadores. Os datos de asistencia máis baixa correspóndenlle á franxa de idade de entre 18 e 26: un 20\% das bandas non conta nunca ou case nunca con este tipo de público. A seguinte táboa mostra con máis detalle esta información. 
Tipo de público que acode normalmente aos concertos das banda segundo a idade

\begin{tabular}{lrrrrrr} 
& $\begin{array}{c}\text { Menores de } \\
12 \text { anos }\end{array}$ & $\begin{array}{c}\text { Entre 12 e } \\
18 \text { anos }\end{array}$ & $\begin{array}{c}\text { Entre 18 e } \\
\text { 26 anos }\end{array}$ & $\begin{array}{r}\text { Entre 26 e } \\
\text { Entre 41 e }\end{array}$ & \multicolumn{2}{c}{$\begin{array}{c}\text { Maiores } \\
\text { de 65 }\end{array}$} \\
\hline Sempre & 8,2 & 3,5 & 7,1 & 16,5 & 40,0 & 58,8 \\
Habitualmente & 37,6 & 24,7 & 21,2 & 57,6 & 57,6 & 37,6 \\
Ás veces & 45,9 & 47,1 & 48,2 & 21,2 & 1,2 & 1,2 \\
Case nunca & 3,5 & 14,1 & 17,6 & 2,4 & 0,0 & 0,0 \\
Nunca & 1,2 & 2,4 & 2,4 & 0,0 & 0,0 & 0,0 \\
\hline \multicolumn{3}{c}{ Fonte: Elaboración propia }
\end{tabular}

\subsection{Difusión e imaxe}

O establecemento de ferramentas de comunicación útiles para que as bandas de música poidan promover as súas actividades e mesmo comunicarse cos seus membros e co seu público é outra das cuestións formuladas na enquisa. A inmensa maioría, case o 99\%, utiliza a rede social Facebook, seguida de Instagram cun 71,8\%. Un $80 \%$ utiliza a edición de carteis e o medio de comunicación tradicional preferido é a prensa escrita (54,1\%). A seguinte táboa mostra os diferentes medios usados polas bandas para dar a coñecer as súas actividades. 
Medios ou ferramentas para difundir as actividades da banda e comunicarse cos seus membros ou co público

\begin{tabular}{lr} 
Redes sociais & Porcentaxe \\
\hline Facebook & 98,8 \\
Twitter & 18,8 \\
Instagram & 71,8 \\
Youtube & 55,3 \\
Tik Tok & 1,2 \\
Outras & 3,5 \\
\hline Medios de comunicación & \\
\hline Televisión & 12,9 \\
Radio & 27,1 \\
Prensa escrita & 54,1 \\
Prensa dixital & 36,5 \\
\hline Outros medios & \\
\hline Páxina web & 40,0 \\
Blog & 7,1 \\
Carteis & 80,0 \\
Mailing & Fonte: Elaboración propia \\
Outros & 18,8 \\
\hline &
\end{tabular}

Para reter e atraer novos públicos, as bandas deseñan certas estratexias divulgativas, entre as que destacan: a innovación e actualización de repertorios (77,6\%), a realización de concertos didácticos e a colaboración con artistas doutras disciplinas como danza, teatro ou monicreques, entre outros (70,6\% en ambos os dous casos). Outras accións máis frecuentes ás que recorren as bandas con esta finalidade son a difusión de programas de man dos concertos (o 67,1\% das bandas) e a organización de ciclos de concertos en datas concretas. 
Estratexias de fidelización ou captación de públicos empregadas polas bandas

\begin{tabular}{lr}
\hline Estratexias & Porcentaxe \\
\hline Concertos didácticos & 70,6 \\
Innovación e actualización de repertorios & 77,6 \\
Implicación directa ou participación do público & 25,9 \\
Difusión de programas de man dos concertos & 67,1 \\
Organización de ciclos de concertos en datas fixas & 62,4 \\
Charlas divulgativas & 9,4 \\
Colaboracións con artistas doutras disciplinas como danza, teatro, & 70,6 \\
monicreques... & 2,4 \\
Ningunha & 14,1 \\
Outras & Fonte: Elaboración propia
\end{tabular}

Xunto co afianzamento do público, o coidado da imaxe pública da banda é outra das cuestións que se tivo en conta neste estudo. O 69,4\% das bandas enquisadas participa con frecuencia en certames, festivais e actos públicos, un 47,1\% interpreta repertorios especializados e un 36,5\% colabora con ONG ou desenvolve algún labor social.

\begin{tabular}{|c|c|}
\hline Estratexias de afianzamento ou mellora da imaxe pública & Porcentaxe \\
\hline Participación frecuente en certames, festivais e actos públicos & 69,4 \\
\hline Invitación de directores/-as ou solistas de renome & 5,9 \\
\hline Organización de cursos ou concursos de renome & 27,1 \\
\hline Interpretación de repertorios especializados & 47,1 \\
\hline Labor social ou colaboracións con ONG & 36,5 \\
\hline Ningunha & 3,5 \\
\hline Outras & 22,4 \\
\hline
\end{tabular}

Fonte: Elaboración propia

A valoración e o parecer que a xente próxima ten sobre as bandas de música (público, alumnado, profesorado etc.) son relevantes para estas co fin de mellorar, renovar ou adaptarse ás suxestións que lles transmitan. Co obxectivo de sondar estas opinións, un 42,4\% das bandas utilizan as redes sociais, o medio máis usado, e case un $30 \%$ usa a caixa de suxestións. Con todo, un 20\% das bandas investigadas non emprega ningún método de medición da satisfacción do público. 
Métodos empregados para coñecer as opinións ou suxestións do público, alumnado, profesorado... co fin de mellorar e adaptarse ás necesidades

\begin{tabular}{lr} 
& Porcentaxe \\
\hline Opinións nas redes sociais & 42,4 \\
Enquisas periódicas & 14,1 \\
Consellos de profesionais e & 24,7 \\
expertos & 29,4 \\
Uso de caixa de suxestións & 20,0 \\
Ningún & 17,6 \\
\hline
\end{tabular}

Fonte: Elaboración propia

\subsection{Desafíos e demandas}

Ante a pregunta aberta formulada na enquisa sobre que aspectos consideran que deberían mellorar no funcionamento e a organización xeral das actividades da banda, as agrupacións expuxeron diferentes cuestións que lles preocupan, entre as que destacan as seguintes:

- A falta de apoio económico. Financiamento

Algunhas bandas mostran a dificultade de manter a asociación sen o apoio económico necesario, o que lles impide desenvolver proxectos, cumprir coa programación, contratar un maior número de profesorado con xornadas laborais máis amplas, mercar material e incluso mellorar as súas instalacións. A escaseza de axudas somerxe as bandas de música nunha situación de debilidade. Para mellorar estas circunstancias demandan un aumento do orzamento por parte das administracións públicas: concellos, deputacións e Xunta de Galicia.

\section{- A falta dun espazo propio (sede)}

Outra das principais demandas das bandas é poder contar cun local para desenvolver con calidade as súas actividades e incluso aumentar a súa programación cultural. A esta necesidade de dispor dunha sede propia hai que engadir o desexo das agrupacións de utilizar outros espazos na súa localidade que lles permitan realizar un maior número de concertos e actividades e dar maior visibilidade ao labor da banda. 


\section{- Políticas de captación}

A captación de novos espectadores e o achegamento das bandas ao público infantil son outras das eivas mostradas. Dentro da xestión das bandas tamén se contempla o desenvolvemento de políticas de captación de músicos, público, alumnado etc.

\section{- Implicación e participación dos socios e da veciñanza}

Nalgúns casos, as bandas demandan un tecido máis amplo de xestores dentro da asociación. A implicación e a participación activa da veciñanza favorecerían o crecemento destas agrupacións musicais. Ademais, reclaman o establecemento de vínculos entre a cidadanía e os socios xa que, na maior parte dos casos, a responsabilidade das bandas está a recaer na persoa que leva a dirección da agrupación.

\section{- Programa de xestión e comunicación}

A mellora da comunicación, sobre todo no eido dixital, é outra das demandas das bandas de música. Igualmente consideran a importancia da aplicación de métodos para coñecer, recoller e valorar as suxestións ou impresións do público, o que podería sentar as bases para deseñar un repertorio ou programación de maior calidade, impulsar iniciativas máis innovadoras etc. Tamén sinalan a necesidade de optimizar os recursos que non son estritamente musicais e que dependen doutras entidades (cadeiras, equipos de son, iluminación, camerinos etc.), para obter o máximo proveito tanto dos concertos como doutras actividades. Estas cuestións acentúanse nas bandas de recente creación.

\subsection{A incidencia da COVID-19 nas bandas}

Esta última parte do traballo céntrase nas consecuencias derivadas da pandemia no funcionamento ordinario das bandas de música, das escolas e das actividades ordinarias destas entidades. Trátanse temas como cuestións laborais do cadro de persoal, o financiamento das actividades, dificultades que tiveron que afrontar na súa actividade regular por mor das medidas de restricións impostas e as reaccións do público como consecuencia dos cambios que tiveron que aplicar. 
En primeiro lugar, con respecto ás posibles consecuencias que se puideron notar no ámbito laboral, indagouse sobre os cambios nas condicións laborais das persoas que traballan tanto nas bandas como nas escolas de música dependentes das asociacións que as sustentan.

Así, preguntóuselles que tipo de medidas laborais se adoptaron co cadro de persoal. Na inmensa maioría dos casos optouse por implantar o teletraballo para o persoal (61,2\%). A seguinte medida á que máis recorreron foi a de acollerse aos ERTE (40\%) e, en terceiro lugar, procedeuse a reducir o horario laboral (17,6\%). Entre as opcións de resposta que se ofreceron, as que obtiveron menos respostas foron as de permisos remunerados e vacacións, cun 2,4\% de resposta cada unha.

Medidas laborais adoptadas polas bandas de música para o cadro de persoal

\begin{tabular}{lrr} 
Medidas & N & Porcentaxe \\
\hline Teletraballo & 52 & 61,2 \\
Manter o persoal en ERTE & 34 & 40,0 \\
Redución do horario laboral & 15 & 17,6 \\
Despedimentos & 4 & 4,7 \\
Permisos remunerados & 2 & 2,4 \\
Vacacións & 2 & 2,4 \\
\hline \multicolumn{2}{c}{ Fonte: Elaboración propia }
\end{tabular}

Con respecto ao financiamento das agrupacións, quíxose analizar ata que punto e con que intensidade se viron afectados os ingresos das entidades por mor da paralización das actividades presenciais nos momentos do confinamento da poboación e, unha vez rematado este, polas medidas restritivas impostas. Nese sentido, os datos que reflicte a seguinte táboa mostran que nun $89,2 \%$ dos casos os ingresos destas entidades se viron reducidos, en $8,4 \%$ dos casos non obtiveron ningún ingreso e tan só no 2,4\% dos casos se mantiveron igual.

Nos casos en que se reduciron os ingresos, obsérvase que non lles afectou a todas as entidades por igual. Así, pódese comprobar por estes datos que 28 entidades se viron afectadas moi seriamente pola redución de ingresos, pois perderon máis dun $75 \%$ das ganancias con respecto ao ano anterior á pandemia. Ademais, un 14,5\% perdeu máis da metade dos ingresos, pero a maioría das entidades que sufriron perdas económicas 
(un 40\%) viron reducidos os seus beneficios en menos da metade dos que obtiveran o ano anterior.

\section{Con respecto aos ingresos obtidos no último ano, como lles afectaron as restricións derivadas da pandemia nos ingresos da banda e/ou escola de música?}

\begin{tabular}{lrr} 
& & Porcentaxe \\
\hline Mantivéronse igual & & 2,4 \\
Non obtiveron ningún ingreso & 8,4 \\
& Ata un 25\% & 19,3 \\
Reducíronse os & Entre un 26\% e un 50\% & 21,7 \\
ingresos & Entre un 51\% e un 75\% & 14,5 \\
& En máis dun 75\% & 33,7 \\
\cline { 2 - 2 } & Fonte: Elaboración propia
\end{tabular}

En canto ás posibles causas que poden xustificar a perda de ingresos e de acordo cos datos que se mostran na seguinte táboa, o motivo que obtivo maior porcentaxe de respostas foi o de cancelación de actuacións, cun 89,4\% de entidades que o alegaron. En segundo lugar e coa mesma porcentaxe de mención, un 37,6\% das entidades xustificaron a perda de ingresos pola redución do alumnado das escolas e pola redución das subvencións públicas. Un 31,8\% apuntaron ás baixas nas cotas de socios/as e, xa por último, cunha porcentaxe máis baixa de resposta, atópase a perda de patrocinadores (16,5\%).

\begin{tabular}{lr} 
Motivos polos que consideran que se reduciron os ingresos (\%) & Porcentaxe \\
\hline Cancelación de actuacións & 89,4 \\
Redución do alumnado & 37,6 \\
Redución das subvencións públicas & 37,6 \\
Baixas nas cotas de socios & 31,8 \\
Perda de patrocinadores & 16,5 \\
\hline \multicolumn{2}{c}{ Fonte: Elaboración propia }
\end{tabular}

Outros problemas non mencionados anteriormente son os seguintes:

- A necesidade de adaptar as instalación e de comprar material para poder cumprir as medidas hixiénicas e sanitarias esixidas.

- A contratación de máis profesorado para cumprir os límites de alumnado nas aulas. 
- A redución de actividades debido á anulación de eventos e festas.

- A imposibilidade de realizar ensaios para poder ter actuacións debido á falta de protocolos para levar a cabo as súas actividades con garantías.

En xeral, en todos os motivos se deixa entrever un temor aos contaxios tanto por parte do persoal directivo das asociación como dos pais/nais do alumnado das escolas e, polo tanto, a necesidade de reducir ao mínimo as actividades de grupo para evitar situacións de risco sanitario.

Un dos contratempos que tiveron que afrontar as bandas de música durante a pandemia, ao igual que moitos outros colectivos que realizan actividades grupais e principalmente nos eventos culturais, foi a imposición de medidas de distanciamento social. Isto dificultou e mesmo impediu as actividades habituais de ensino das escolas de música e outras propias das bandas, como poden ser os ensaios colectivos e, sobre todo, a cancelación de numerosos concertos.

Un 70,1\% das entidades enquisadas considera que diminuíu o apoio das administracións públicas xa que ou ben se reduciron as subvencións ou deixaron de contratalas como o facían en anos anteriores á pandemia. Ademais, o 72,6\% das entidades viu diminuídos os ingresos proporcionados polo alumnado das escolas de música debido tanto á redución dos recursos económicos das familias (39,7\%), como á falta de medios para impartir as clases coas medidas de seguridade impostas (32,9\%). Por outra banda, un 53,8\% das escolas tamén viu reducidos os recursos pola limitación de capacidade das aulas para impartir clases colectivas.

Por último, cómpre salientar que, ademais da redución de ingresos, un $74,1 \%$ das bandas tiveron que soportar un incremento importante nos gastos debido á necesidade de mercar material de protección e hixiene esixido para poder desenvolver as súas actividades. 


\section{Repercusións económicas das medidas de distanciamento social impostas pola} pandemia (\%)

Si Non Ns/Nc

Supuxeron un incremento importante nos gastos para compra de materiais de protección e de hixiene

$74,1 \quad 22,2 \quad 3,7$

Houbo moitas cancelacións de concertos que implicaron unha redución importante dos ingresos

$95,2 \quad 4,8$

Falta de apoio das administracións públicas por redución de axudas ou pola ausencia de contratos para actuacións

$70,1 \quad 22,1 \quad 7,8$

Redución dos patrocinios por falta de seguridade

Redución do alumnado da escola por falta de medios para impartir as clases coas medidas de seguridade impostas

$32,9 \quad 50,0 \quad 17,1$

Redución do alumnado da escola por baixada de recursos económicos do alumnado

$39,7 \quad 33,3 \quad 26,9$

Redución dos recursos da escola de música pola limitación da capacidade da aula

Fonte: Elaboración propia

Por último, considerouse moi importante analizar a reacción do público á hora de asistir aos concertos, unha vez que se relaxaron as medidas restritivas e se puideron levar a cabo. Así, pódese observar nos datos da seguinte táboa que un 31,8\% do público habitual dos concertos deixou de asistir por medo aos contaxios ou inseguridade $(24,7 \%)$ ou por considerar que non se debían organizar actividades culturais con público $(7,1 \%)$.

En canto ás persoas que si asistiron aos concertos, un $24,7 \%$ das bandas considera que asistiron moitas menos persoas do habitual, o cal pode deberse ás limitacións de capacidade nos recintos onde se levan a cabo os concertos. Ademais, un 5,9\% cre que asistiron persoas distintas das habituais. 


\section{Reacción do público con respecto aos concertos das bandas}

$\begin{array}{lr} & \begin{array}{r}\text { Porcent } \\ \text { axe }\end{array} \\ \text { Asistiron moitas menos persoas do habitual } & 24,7 \\ \text { Asistiron persoas distintas das habituais } & 5,9 \\ \text { Houbo persoas que deixaron de asistir por considerar que as } & 7,1 \\ \text { actividades culturais con público non se debían organizar } & \\ \text { Moitas persoas deixaron de asistir por medo aos contaxios ou por } & 24,7 \\ \text { inseguridade } & \\ \text { Outras } & 10,6\end{array}$

Fonte: Elaboración propia

\section{Conclusións}

Este informe é o resultado dunha colaboración entre o Consello da Cultura Galega e a Federación Galega de Bandas de Música Populares. O obxectivo do estudo é cuantificar a súa dimensión social, profesional e académica, así como describir os problemas que xurdiron por mor da crise da pandemia.

Fíxose un cuestionario proposto á Federación Galega de Bandas de Música Populares para que contestasen as bandas asociadas, con preguntas suxeridas pola propia Federación e baseadas noutras enquisas publicadas en traballos similares. Ademais, para a segunda parte do traballo, referida ás consecuencias da pandemia, tívose tamén en conta o cuestionario en que se baseou o barómetro da cultura galega realizado polo Observatorio da Cultura Galega para analizar este mesmo aspecto nas industrias culturais galegas.

O universo de estudo son as bandas de música asociadas á Federación Galega de Bandas de Música Populares. Das 94 entidades federadas contestaron ao cuestionario 85. Este aplicouse de maneira telemática entre o 28 de abril e o 17 de maio de 2021. Os resultados supoñen unha explotación das frecuencias das preguntas das bandas que participaron no estudo.

A distribución xeográfica das bandas de música federadas revela que é a provincia de Pontevedra a que achega a cifra máis elevada de 
agrupacións, con 52, seguida da da Coruña con 28 e, xa a máis distancia, a de Lugo con 9 e a de Ourense con 5.

A importancia das bandas de música populares en Galicia maniféstase claramente en tres dimensións: unha sociocultural, outra educativa e unha última de tipo laboral e económica.

Con respecto á dimensión sociocultural, cómpre salientar, en primeiro lugar, que as diferentes agrupacións musicais galegas entrevistadas están integradas por unhas 7.100 persoas, o cal evidencia a relevancia social destas entidades, que contan cunha medida de 85 socios cada unha, unha antigüidade que rolda os 61 anos e unha actividade ininterrompida dende a súa creación.

Estas asociacións musicais están conformadas por diferentes agrupacións ou seccións, ademais das propias bandas principais, cunha representación dun $21,6 \%$ de bandas xuvenís e dun 13,5\% de bandas infantís. O 88,6\% destas bandas de música dispón dunha xunta directiva formada por un grupo de entre cinco e dez membros, dos que un 45,5\% son mulleres.

Verbo dos intérpretes das bandas, os datos reflicten que os da sección vento-madeira son os que conforman máis da metade, concretamente un 55,8\%. De feito, un 22,2\% dos instrumentistas das bandas tocan o clarinete. En segundo lugar, os intérpretes de instrumentos de vento-metal suman o 31,5\% dos músicos, sendo os trompetistas os que integran o maior número de intérpretes desta sección. A continuación van os percusionistas, cun 10\% dos membros das bandas. Por último, constátase que os instrumentos de corda teñen pouca presenza nas bandas de música, concretamente conforman un 2,7\% dos músicos das bandas, o cal semella algo lóxico porque non son instrumentos habituais das bandas e moitos conservatorios/escolas de música só imparten aulas de violín.

Son músicos cunha excelente formación porque un $71,8 \%$ das bandas de música obxecto deste informe conta con intérpretes que teñen titulacións oficiais de música: o 44\% posúe unha titulación de grao elemental, o 35,3\% de grao profesional e o 20,7\% de grao superior. Tamén 
moitos se atopan en formación, xa que 1.701 dos seus compoñentes estudan algún tipo de ensino regrado da música (o 24,5\% o grao elemental de música, o $58,7 \%$ o grao profesional e o $16,8 \%$ o grao superior).

Esta dimensión sociocultural está directamente relacionada coas actividades que realizan en distintos contextos, especialmente no seu contorno xeográfico, e a súa relación co público que asiste aos seus concertos.

Así, constatouse que o radio de actuación das bandas de música é eminentemente local ou comarcal para máis do 90\% delas, xa que os concertos se circunscriben á participación nos actos festivos dos seus concellos ou vilas, aínda que máis da metade $(51,8 \%)$ tamén os ofrece noutros municipios da mesma provincia. As actuacións fóra de Galicia e incluso do país son moi baixas, un 2,4\% e un 3,5\% respectivamente.

As comisións de festas e o propio concello onde radica a banda son os principais encargados da súa contratación. Case o $92 \%$ das bandas utiliza os espazos e as prazas públicas para realizar os seus concertos e un $87,1 \%$ faino en auditorios. Ademais das prazas, os recintos ao aire libre máis usados son os parques e xardíns $(65,9 \%)$ e os palcos de música (64,7\%). No caso dos recintos cubertos, os lugares máis empregados son as igrexas, catedrais e mosteiros (40\%).

Con respecto á asistencia de público aos concertos, para o 28,2\% das bandas de música, a asistencia media aos concertos é de entre 50 e 100 persoas. En canto ao perfil do público que acode aos concertos, constátase que no 58,8\% dos casos os espectadores que acoden sempre son as persoas maiores de 65 anos. A frecuencia na asistencia descende coa idade.

As bandas de música adoitan utilizar algún sistema ou ferramenta para difundir as súas actividades e comunicarse cos seus membros ou co público. As redes sociais e os medios de comunicación son algúns destes instrumentos de divulgación. O 99\% das agrupacións enquisadas utiliza Facebook, seguida de Instagram cun 71,8\%. Un 80\% utiliza a edición de carteis e o medio de comunicación tradicional preferido é a prensa escrita (54,1\%). 
A valoración do labor das bandas por parte do público, alumnado, profesorado etc. é relevante para estas co fin de optimizar o seu funcionamento. Co obxectivo de sondar estas opinións, un 42,4\% das bandas usa as redes sociais e case un 30\% utiliza a caixa de suxestións. Con todo, un $20 \%$ das bandas investigadas non emprega ningún método de medición da satisfacción do público.

Unha segunda dimensión está relacionada coa magnitude formativa e educativa que implica a actividade das bandas de música, non só pola propia formación especializada que posúen os seus membros, senón tamén polo propio labor educativo en formación musical que exercen as escolas de música asociadas ás propias bandas.

Existe una gran vinculación entre as bandas de música e o ensino desta arte. En Galicia hai 5 escolas de música de titularidade pública por cada 100.000 habitantes, o dobre que no total de España. Este dato cobra máis relevancia cando se ten en conta que Galicia ocupa o segundo lugar neste indicador, se se compara co conxunto das comunidades autónomas.

É precisamente neste contexto de ensino da música no que se encadran as bandas de música populares de Galicia. Aínda que moitas están constituídas como asociacións e teñen as súas propias escolas de música, tamén é certo que moitos dos seus músicos se forman na práctica instrumental nas escolas municipais de música.

Un 71,4\% das bandas de música galegas enquisadas dispoñen de escola de música e un 60,4\% están formadas por alumnado que procede das propias escolas das asociacións ás que pertencen as bandas, ás que asisten un total de 7.114 alumnos, dos cales un $50,7 \%$ son mulleres.

En xeral, as bandas estudadas valoran satisfactoriamente o funcionamento das escolas de música, sobre todo naqueles aspectos relativos aos recursos humanos e ao nivel formativo. Para o 90,8\% delas a atención do profesorado obtén unha valoración moi positiva, ao igual que a calidade da formación da escola e a ratio profesorado/alumno. No primeiro caso, un $86,2 \%$ outórgalle unha valoración moi boa ou boa e no segundo caso un $83,1 \%$ deulle esa mesma valoración. Os métodos de ensino, a xestión da escola, a realización de actividades, a organización 
xeral e a flexibilidade de horarios tamén son avaliados de xeito notable por máis do $70 \%$ das bandas de música.

O aspecto máis cuestionado ten que ver coas instalacións, xa que un $28,8 \%$ cre que son malas ou regulares. Algo similar sucede coa dispoñibilidade de instrumentos cos que conta o alumnado, dado que un $21,5 \%$ das bandas enquisadas estima que é regular, mala ou moi mala. Hai que ter en conta que estas agrupacións musicais son deficitarias nalgún tipo de infraestruturas.

Neste sentido, o 68,4\% destas non ten equipo de gravación, un 64,1\% carece de vehículo de transporte propio, un 55\% non dispón de cabinas de estudo e un 35\% non conta con auditorio. $\mathrm{O}$ arquivo de partituras ten unha calidade media para un $43,8 \%$. A valoración máis baixa por parte das bandas populares ten que ver sobre todo coas oficinas de administración, xa que un $37,5 \%$ as cualifica cun nivel baixo de calidade. No caso das salas de ensaio tamén se aprecia unha valoración moderada: un $37,5 \%$ das bandas considera que a calidade destas é media e un 33,8\% baixa.

Unha terceira dimensión analizada ten que ver cos aspectos profesionais e económicos implicados na actividade regular das agrupacións e das asociacións nas que están integradas. A maioría destas asociacións ten persoal contratado, concretamente o 83,5\%. O 40,6\% ten ata 5 persoas contratadas e un $24,6 \%$ dispón dun cadro de persoal formado por entre 11 e 15 persoas. Os postos de traballo máis ocupados son os de director/-a da banda $(67,1 \%)$ ou o do profesorado $(55,3 \%)$.

No que respecta á dirección das bandas, o 58\% ten só un director/a da banda principal, un $24,7 \%$ conta con dous e un $16,5 \%$ con máis de dous. O perfil dos directores/as das bandas é o dunha persoa que ten unha media de case dez anos de antigüidade nese posto, cunha xornada laboral media de entre 6 e 10 horas semanais, cun contrato indefinido $(35,7 \%)$ e con formación especializada, xa que o 55,3\% posúe unha titulación superior en ensinanzas regradas da música e un 32,9\% ten formación específica en dirección de banda ou orquestra. Hai asociacións que contan cun segundo director que dirixe principalmente as bandas infantil e/ou xuvenil (un 51,9\%) ou coral (11,1\%). 
No que atinxe ao financiamento, as asociacións empregan distintos instrumentos para poder soster as súas actividades. Os principais son os honorarios por actuacións e as subvencións públicas, que nos dous casos acadan unha porcentaxe dun $85,9 \%$. A maioría das bandas de música, un $63,4 \%$, obtén uns ingresos de ata 30.000 euros. Tan só un $9,8 \%$ das bandas de música recibe ingresos superiores a 80.000 euros.

Unha parte deste informe estivo dedicada a analizar a repercusión da pandemia provocada pola COVID-19 na actividade habitual das bandas. Verbo dos aspectos laborais, adoptáronse medidas como o teletraballo para o persoal nun 61,2\% dos casos e aplicaron un ERTE un 40\% das entidades. No que atinxe aos ingresos obtidos neste período con respecto á etapa anterior á pandemia, tan só o 2,4\% dos casos mantivo os ingresos e o resto reduciunos ou mesmo non tivo ningún tipo de ingresos. A caída de ingresos debeuse principalmente á cancelación de actuacións (89,4\% dos casos), á redución do alumnado das escolas e á diminución das subvencións públicas (37,6\% dos casos). Un 31,8\% do público habitual dos concertos deixou de asistir por medo aos contaxios ou inseguridade ou por considerar que non se debían organizar actividades culturais con público.

Ademais dos aspectos destacados, tamén se detectaron algunhas eivas a partir da análise que fan as bandas nas preguntas abertas que se formularon. Unha das máis relevantes é que se percibe falta de apoio económico. En xeral demándase un incremento do orzamento destinado ás bandas por parte de todas as administracións públicas.

Outra das demandas básicas ten que ver co feito de poder contar cun local para desenvolver con calidade as súas actividades e incluso aumentar a súa programación cultural. A esta necesidade de dispor dunha sede propia hai que engadir o desexo das agrupacións de utilizar outros espazos na súa localidade que lles permitan realizar un maior número de concertos e dar maior visibilidade ao labor das bandas.

Reclaman así mesmo o desenvolvemento de políticas de captación de músicos, público, alumnado etc., así como unha maior implicación e participación dos socios e da veciñanza para favorecer o crecemento 
destas agrupacións musicais e establecer vínculos entre a cidadanía e os socios.

Tamén son conscientes da necesidade de mellorar a comunicación, sobre todo no eido dixital, para coñecer, recoller e valorar as suxestións ou impresións do público, o que podería sentar as bases para deseñar un repertorio ou programación de maior calidade, fomentar iniciativas máis innovadoras e, en definitiva, promover o labor cultural e social que impulsan as bandas de música populares. 